\title{
Rights, obligations and citizenship
}

Three related concepts are addressed here: rights, obligations and citizenship. We first consider the development of the concept of 'rights' as being intrinsic to human beings because they are human. Different interpretations of the term 'rights' are discussed together with some of the controversies which surround the issue at the present. Next we analyse the idea of 'obligation' or 'duty', notably the obligations the citizen is said to owe to society and to the government. Various theories of such obligation are examined. We look at the currently fashionable idea of 'citizenship', and the various ways in which the term is used. Lastly, we reflect upon the implications of the present British government's promotion of 'citizenship'.

\section{POINTS TO CONSIDER}

> Is it reasonable to claim that there are universal human rights that should be upheld by all governments?

- Should 'positive' rights be included among universal human rights since their observance depends on resources beyond the scope of most governments?

- Has the experience of totalitarianism confirmed the traditional liberal view that the main threat to human rights comes from the state?

> Does acceptance of 'rights' automatically imply an acceptance of duties?

- To whom or what is the citizen's highest duty owed?

Does the term 'citizenship' imply both legal rights and social obligations?

> Does the government's emphasis on the duties of citizenship conceal the possibility that it is reneging on its own duties? 
Wherever there is a human being, I see God-given rights inherent in that being, whatever may be the sex or complexion. (William Lloyd Garrison, Life, 1885-89)

All, too, will bear in mind this sacred principle, that though the will of the majority is in all cases to prevail, that will to be rightful must be reasonable; that the minority possess their equal rights, which equal law must protect, and to violate would be oppression. (Thomas Jefferson, first inaugural address, 4 March 1801)

All human beings are born free and equal in dignity and rights. (Article 1, Universal Declaration of Human Rights, 1948)

\section{Rights}

The concept of 'rights' is nowadays so familiar, and so intertwined with that of 'democracy', so much part of everyday usage and serious political discourse that it is surprising to discover that 'rights' in the modern sense are very much a creation of the seventeenth and eighteenth centuries.

Although today 'democracy' is universally assumed to presuppose the existence of 'rights', the democracy of the Greek city-states functioned without this concept at all. Certainly, there were some people who had the right to vote, but this was because they were 'citizens'; the franchise was by no means universal, and only male citizens had the vote.

In feudal times there was certainly a notion of rights but the word 'right' was closer in meaning to our modern idea of 'property'. Individuals and groups had rights to do various things - to hold markets, to graze animals on specific common lands - but these rights were specific to them as individuals. They did not enjoy them because they were citizens, still less because they were human beings. Medieval society was a complex tapestry of such rights; rights which also often involved duties, such as providing monies or armed forces

feudalism

A social structure based on strict social differentiation and involving rigid reciprocal rights and obligations. Feudalism was the social structure of medieval Europe. for their lord or king. As late as the English Civil Wars of 1642-49, Parliament's stand against the king was justified as a defence of 'ancient and undoubted rights and privileges'.

The whole business of rights has in fact been a greater source of controversy than their currently fashionable acceptance would suggest. Eighteenth-century conservative thinkers vigorously contested concepts of the 'rights of man', most notably Edmund Burke. Burke argued that rights did not exist in the abstract as 'human rights', but only in the concrete and specific world of a political system. One could certainly enjoy rights as an Englishman or a Frenchman, as the subject of a state, but not as 'man' in general. Socialist thinkers were also, at least initially, less than enthusiastic about rights, particularly individual rights. Like Burke they tended to emphasise group rights, in this case the rights 
of the working class or trade unions. The far left tended to dismiss the whole idea of individual rights as a disguise for the actual exploitation of the working classes, whatever theoretical 'individual' rights they might enjoy. Thus while liberals argued for the individual's right to enter into economic relations, to make bargains and contracts, socialists argued that the possession of such rights ignored the plain fact that the 'playing field' was far from level. In fact, it was tilted steeply against the working class, whose relative social and political weakness made bargaining with employers unequal.

Events in the twentieth century were to modify this belief drastically. Liberals were forced by the inter-war slump to realise that individualism was not enough. The atrocities of the Nazi period forced conservative thinkers to accept that there were real 'human' rights. The experience of Soviet-style communism led the left, even the far left, to a reluctant acquiescence in recognising the importance of upholding individual rights as a defence against the might of totalitarian regimes.

Thus the post-war period was notable for a plethora of proclamations of 'rights'. Human rights were espoused by the Vatican and adopted by the United Nations. Even the British, suspicious of legalistic positive rights, eventually incorporated the European Convention on Human Rights into law. The UK was the first to sign the Convention in 1950 and the last to adopt it as part of its domestic law in 2000. Political demands were often articulated in the language of rights: minority rights, women's rights, gay rights, even animal rights. There were assertions of national 'rights to self-determination' after the First World War, the right to suicide, rights to ingest harmful drugs, the 'right to choose' (to have an abortion), and so on. Ordinary speech soon translated wishes into the language of rights - the right to have children, to various forms of sexual experience, to foreign travel and to self-expression and discovery.

Such language actually tended to debase the whole concept of rights and rob it of meaning.

Moreover, it soon became apparent that simply upholding rights was by no means an uncontentious formula for government action. Rights became highly contentious, as it soon became apparent that there was no universal agreement as to what specific legal or civil rights there should be. Should women, for example, have an exclusive 'right to choose' to have an abortion or not? Such a right would conflict with a child's 'right to life', the right of the father to a say over the welfare of his progeny, and the right of society to ensure sufficient citizens are produced to guarantee its survival. Many other controversial issues spring to mind. Are rights absolute? Does the right to life extend to all persons in all circumstances? If one has a right to life, does one also have the right to end it? Where do the right to freedom of speech end and the right to privacy, and to freedom from racial harassment, begin? 
If anything, an appeal to alleged rights does not end controversy; it merely gives it a powerful emotional charge.

Further difficulties have arisen as philosophers have tried to establish the rational basis of human rights. John Locke, for example, argued that human rights are 'God-given', but modern secularisation has lessened the impact of this assertion. Man's claim to special treatment among living things by virtue of his capacity for moral choice, his intellectual pre-eminence and his manifest superiority to the animal kingdom, has been shaken by scientific advances. As a result, some argue for animal rights to be as valid as a human's and that man has a moral obligation to observe them. In fact, animal rights campaigners question the entire legitimacy of a political system based on rights that apply only to humans.

\section{The nature of rights}

At this point it might be useful to distinguish between various kinds of rights. Four types can be suggested:

- 'natural' and 'human' rights;

- legal rights;

- civil rights;

- welfare rights.

\section{'Natural' and 'human' rights}

Natural or, in today's terminology, human rights are held by people as part of their very humanity. They are a gift from God or nature to every human being. The state is the guardian of such rights, not the creator of them. To deprive human beings of such rights is therefore morally wrong. Governments are obliged to uphold these rights; if a government does not, it acts immorally.

The most articulate early exponent of this view was John Locke, writing in the late seventeenth century. In his Two Treatises on Government (1690) he itemised these rights as 'Life, Liberty and Property'. Eighty-six years later, Thomas Jefferson wrote this principle into the American Declaration of Independence as 'Life, Liberty and the pursuit of Happiness'. This proclamation of the centrality of rights in the system of government implied that government was 'good' in so far as it observed these rights, a doctrine which had important consequences for the institutions of government, and for the principles of which they were the expression. One such principle is the 'separation of powers' in the US Constitution which has separate bodies for the legislature (Congress), executive (President), and judiciary (Supreme Court). The framers of the American Constitution further assumed that limited government would be in practice essential if rights were to be preserved. Moreover, the whole legitimacy of the American War of Independence itself 
was predicated on the assumption that 'rights' are essential to decent human existence - so essential, in fact, that there was in nature itself another 'right', the right to rebel: 'whenever any Form of Government becomes destructive of these Ends it is the Right of the People to alter or abolish it, and to initiate new government' (Declaration of Independence, 1776).

\section{Legal rights}

Legal rights are those which are enforceable in courts of law. These may derive from natural rights but are not identical to them. Thus, for example, a child might be said to have the human right to life, but not the legal right to vote or dispose of property.

\section{Civil rights}

The term civil rights is sometimes applied to legal rights but more often refers to rights which do not actually exist in law but which in some sense ought to exist, or to rights which may exist on paper but not in reality. Civil rights are held to be essential for the satisfactory functioning of society. Thus the civil rights movement in America in the 1960s campaigned for non-discrimination towards African-Americans in education, transport and restaurant facilities. In Northern Ireland the civil rights movement of the late 1960s campaigned for a wide measure of social justice in housing and jobs, as well as in 'genuine' democratic institutions and non-sectarian policing.

\section{Welfare rights}

Welfare rights include the right to employment, education and adequate healthcare. Such rights are, it is claimed, 'positive' rights, as opposed to the 'negative' rights that protect the individual from the actions of a tyrannical state. As has been suggested, the liberal approach to rights, exemplified by Locke and, later, J. S. Mill, assumes that the greatest potential threat to rights is the state - the state whose prime function ought to be the very protection of these rights.

By the late nineteenth and early twentieth centuries, though, many thinkers had come to regard this fear of the state as misplaced. The real threat to vast numbers of people, they argued, is not the state but powerful institutions and ingrained economic and social forces before which the ordinary citizen is powerless. This understanding implied a positive role for the state as the guarantor and even provider of welfare rights.

This new conception of rights has had a major influence on the European Union. In 1989 the Commission proposed a draft 'Charter of Fundamental Social Rights', concerned with conditions of work, minimum wage rates, equal 
opportunities and so on. That charter was eventually incorporated into the Treaty of Maastricht (1992) as the 'Social Chapter'.

The reappraisal of rights and the role of the state in providing them have not been without controversy. Some have argued that these are not 'rights' in the usual sense at all, since they are contingent on the state's actually being able to supply them. If they are rights at all, they are better described as 'aspirational rights'; in other words, they are desirable objectives but not necessarily ones that are possible to implement practically.

\section{Obligations}

Although much attention has been paid to 'rights' in recent years, some consideration is now being given to 'duties' (or, as it has become more usual to call them, 'obligations'). The implicit assumption is that rights need to be balanced by duties. Historically, the left has been more anxious to stress rights; nowadays even the liberal left has focused on duties. In part this is a consequence of the development of the belief in 'civil society', the network of family, voluntary and informal groups and activities that underpin a decent society. This belief derives partly from a reaction to the rampant individualism of the Thatcher years. Another source of this belief is an analysis of the weaknesses of the former communist regimes of Eastern Europe, regimes in which there were no intermediate stages, no buffer, between the state and the individual.

Since 2000 both the Labour and Conservative parties in Britain have stressed the need for people to recognise their public duties and to act upon this recognition.

\section{The nature of obligations}

As with rights, the terms duties and obligations cover a number of rather different concepts, which may be summarised as follows:

- moral obligations;

- legal obligations;

- civic obligations;

- social obligations.

\section{Moral obligations}

Moral obligations are the things people ought to do because in some sense they owe such actions to God, to others or to themselves. Thus there is a moral obligation to speak the truth, to help others in need, to refrain from adultery, and so on. These obligations are not enforceable by law in Britain (although in some countries they are: adultery is illegal in Saudi Arabia; failing to assist an injured person is illegal in Spain). Moral obligations do, however, often become the basis of legal obligations, as the foregoing examples illustrate. 
Legal obligations

Legal obligations are things one has to do which are enforceable in the courts, such as paying one's taxes and driving only when in possession of a valid driving licence. Such obligations are closely linked to state sovereignty. Citizens and other individuals resident in the territory of a state are under an obligation to obey the laws of that state.

\section{Civic obligations}

Civic obligations are actions we should perform as a tribute to the rights we enjoy as part of a political community. We may be said to have the right to vote and also the civic obligation to do so. (In some countries, such as Australia, this is a legal obligation which incurs a fine if breached.)

\section{Social obligations}

Social obligations are an extension of civic obligations. They involve a broadly similar concept but have wider application. They include those obligations we owe to society that contribute to the general good. Such duties are only tangentially linked to specific rights. For example, one might claim the right to have children and decide on their education. The concomitant obligation would be to bring them up properly, as good citizens, introduce them into the culture of their society, and teach them right from wrong. Such obligations can be discharged on a personal and an individual basis. The present British government encourages people to fulfil their obligations by operating within groups and organisations of all kinds; for example, the obligation of childcare can include the care of other children besides one's own, by such means as working in the Guide or Scout movements.

\section{The sources of obligations}

By and large, obligations have proved less contentious than rights. Many supposed obligations seem little more than pious aspirations with which no one would quarrel. There are few campaigns, violent or otherwise, in defence of an extension of obligations. This is not, however, to say that there are no areas of dispute. One question concerns the source of such obligations. If they are to be taken seriously they need a firmer grounding than just decent feelings.

The earliest basis for asserting the binding nature of obligation is the idea of contract. In a sense this can be traced back to the biblical notion of the covenant of God with His people, who keep His laws in exchange for His protection.

Of greater importance to our deliberations here, though, are the theories concerning the notion of a social contract which were devised in the seventeenth century by Thomas Hobbes and John Locke. Both men sought to explain 
the origins of government by reference to a state of nature, a situation of primal chaos caused by the absence of established authority. Having logically discerned what such a condition would be Hobbes and Locke used logic to establish the basis for government and the obligation of the citizen to

state of nature

Human society as it was before the establishment of

government characterised by total freedom and the absence of law or authority. obey. In such situations, they argued, human beings established a 'contract' between the governed and the governors. This formed the basis for both rights and obligations of both parties. Neither writer regarded the 'state of nature' and the subsequent creation of a contract as historically based; they both saw it as a sort of metaphor, an 'explanatory myth'.

Hobbes, in Leviathan (1651), argued that in order to escape the barbarism of the 'state of nature', where every man was pitted against every other in an endless cycle of violence and distrust, human beings voluntarily surrendered their unbridled freedom to an authority, a government, which subsequently had absolute claims on their obedience. As long as such a government provided security for those people they were obliged to support it. However, should the government fail in this crucial duty then the citizenry were released from their obligation to obey and were, in fact, obliged to obey any new government able to offer them security.

A less totalitarian interpretation of the social contract was that of Locke. His state of nature was not one of instability and violence. Human beings could maintain order and peace without government, but government was necessary to provide a stronger framework for the protection of their natural rights. In his Two Treatises of Government (1690), Locke argued that there were in effect two contracts. The first was one in which individuals agreed to impose limits on themselves to form 'society'. The second was a contract between society and government by which government would be obeyed in exchange for its protection of natural rights. Both contracts form the basis of liberal ideas of politics and government.

Conservatives have not been impressed by Locke's thesis, particularly by its dependence on a belief in 'natural rights'. Instead, they have suggested that every individual owes a natural loyalty to his society, in much the same way as he bears a loyalty to his own family: "We begin our public affections in our families. No cold relation is a zealous citizen. ${ }^{1}$ Society and the family are natural rather than artificially contrived institutions and can therefore rightly lay claim to a natural obligation.

A more pragmatic argument is one based on the value to the individual of fulfilling his obligations to society and, by extension, to the government. A 'good' government will, in the words of Jeremy Bentham, pursue 'the greatest happiness of the greatest number'. This principle is called utilitarianism. 
Questions necessarily arise. Are obligations to society the same as obligations to the state? If not, what if there is a clash between the two? If we equate 'state' with 'nation' then much conflict might well occur. For example, Germany defeated France in 1940. The French government surren-

\section{utilitarianism}

A political philosophy that sees the highest political goal as promoting the 'greatest happiness of the greatest number'. dered and ordered its armed forces to cease hostilities. Some Frenchmen, such as Charles de Gaulle, felt this as a betrayal of the French nation by the French state. In his view this betrayal absolved him of all loyalty to the (admittedly legal) government of Marshal Philippe Pétain that emerged after the fall of France. Indeed, de Gaulle and his followers believed that they had not only the right to continue the war, but a positive obligation to do so.

Yet another question arises. Can the 'nation' be equated with 'society'? Or is there a global society that has an equal, if not superior, claim on loyalty? Other claimants to loyalty may also be considered: conscience, race, class, church, religious community, the environment, even the human race itself. All of these may, in certain circumstances, appear to have a greater claim than the state or nation.

Even if it is admitted that the state has valid claims to obedience (and Marxists and anarchists explicitly reject such claims), what is the nature of that obedience? Is it simply observing the law or does it go beyond that to a positive and enthu-

\section{totalitarianism}

A political system in which the government controls all areas of political, economic, social and cultural life. It allows no opposition and effectively eliminates 'private' life. Examples of such totalitarian societies include Nazi Germany and the Soviet Union. siastic support of the regime? Totalitarian states, like Nazi Germany, clearly demanded unconditional obedience to the state (regarded by them as the ultimate representation of the Volk or 'people').

Liberal theorists have argued that there are limits to the obligations which the state can impose on people. They have proposed specific constitutional arrangements to give effect to these limitations. Liberals assume that the state's role in society is very largely to safeguard natural or human rights.

A problem arises if the state does not, in fact, guarantee such rights. At what point does the bond of obedience dissolve? Is there a right of the citizen to rebel against, and even overthrow, such a state by force? This question has, of course, been of acute interest in the twentieth and early twenty-first centuries, but originally arose in the seventeenth and eighteenth centuries. Locke argued that there was such a right and the argument was made explicit in the American Declaration of Independence (1776), which boldly asserted that when government degenerated into despotism 'it is the right of the people to alter or abolish it, and to institute a new government'. 
Even if it is accepted that there is such a right to revolt, difficult questions arise as to precisely what circumstances justify such a rebellion and whether there should be any constraints on the methods of the revolutionaries. These questions, of course, are points not simply of academic interest, but of urgent contemporary political importance. As early as the thirteenth century Thomas Aquinas had laid down certain conditions for justified rebellion that were subsequently absorbed into the writings of other theorists. The Latin American bishop Oscar Romero of San Salvador has in the twentieth century reiterated this view: "When a dictatorship seriously violates human rights ..., when it becomes unbearable and closes channels of dialogue ..., the church speaks of the legitimate right of insurrectional violence. ${ }^{2}$ The main criteria were that oppression was intolerable, that no other means were available, that the good done would exceed the harm, that there was a reasonable chance of success and that the struggle be conducted by 'just means'. Many of these principles were also associated with those of the just war, for example avoiding deliberate injury to the innocent. In practice such conditions are necessarily highly subjective.

\section{Citizenship}

'Citizenship' appears to be enjoying something of a vogue. It has been incorporated into the lexicon of the major parties and the present British government (2002) intends making classes in 'citizenship' part of the National Curriculum. The general impression given is that a 'good citizen' more or less equates with a 'good person', and what is 'good' appears to be what is held to be so in contemporary society. Hence, much emphasis is apparently to be placed on 'tolerance' as a value to be promoted in citizenship classes.

\section{The nature of citizenship}

There is more to the term 'citizenship' than simply pious do-gooding. It is a word capable of multiple meanings:

- legal citizenship;

- sociological citizenship;

- participatory citizenship.

\section{Legal citizenship}

Legal citizenship can simply mean 'having legal status'. A citizen of a country enjoys certain legal rights (for example, to live and work there) in contrast to 'aliens' who may be admitted and may enjoy some of the rights of citizenship, but not all. Legal citizenship may well involve political rights, such as the right to vote, campaign and stand for public office. 


\section{Sociological citizenship}

This category, 'sociological', means that a person may be a 'citizen' of a country (or of a larger unit, such as the European Union) as well as holding other identities such as race, class, religious affiliation and so on. One can, of course, also be a citizen of a city (indeed, 'city' is the root origin of the word), and proud of it. Cicero, the Roman writer and politician, was proud of being a Roman citizen: civis Romanus sum ('I am a Roman citizen').

Cicero's pride in his Roman identity suggests that there is something more to citizenship than just legal status or sociological classification. It indicates an emotional tie with that identity. In most understandings of citizenship there is a sense not only of the right, but also of the privilege of participation in society as a matter of pride, even of honour and duty.

\section{Participatory citizenship}

The idea of 'participation' as an important feature of citizenship has raised the issue of what in reality (as aside from formal legal provision) makes such participation possible. Obvious factors include the opportunity to work and to contribute to society, a reasonable level of income, access to public authorities and channels for the expression of views.

There are many in society to whom these desiderata do not in fact apply: 'second-class citizens', the 'excluded', the 'underclass'. Recently government attention has been given to regeneration schemes, skills training, social welfare benefits, so as to bring these people within the normal functioning of society - in short, to make them citizens. This necessitates the empowerment of the socially excluded by means ranging from consultation mechanisms to advocacy schemes (whereby a trusted person acts as 'advocate' for the less articulate and educated members of society).

One problem with this approach is its open-endedness. Just what constitutes normal participation in society - being able to afford Christmas and birthday presents, holidays abroad, tickets for football matches? There is also the practical difficulty of the cost to the state (or really to its taxpayers) of such initiatives. A further criticism is that state intervention in this area is counterproductive. Far from being empowered, the subjects of this intervention are in fact made dependent on the state. A 'dependency culture' emerges in which the poor, ethnic minorities and other under-privileged citizens have their selfreliance undermined. They may eventually come to expect the local council or the state to do everything for them, with disastrous consequences for themselves and the wider society.

In reaction, therefore, to the notion of 'social citizenship', in which the state intervenes to ensure a measure of social equality, right-wing commentators 
have redefined citizenship in terms of not being a burden, of contributing to society positively by hard work and engagement in various voluntary activities. These activities create what the Conservatives have recently called a 'neighbourly society'.

A similar concept of citizenship seems also to have informed New Labour's approach to the matter. One aspect of Tony Blair's 'Third Way' is a fruitful partnership of the public, private and, crucially, voluntary sectors in improving the community. In this vision the state would aid charities by funding assistance, expertise, 'charity friendly' regulations, and so on. Such a project would rely heavily on volunteers, on 'active' citizens.

For both the Labour and Conservative parties these versions of citizenship represent a considerable divergence from previously held positions. The Conservatives under John Major introduced a 'Citizen's Charter' which provided quality benchmarks for public services such as hospitals and railways. By doing so, they redefined the citizen as essentially a consumer of services rather than as an active participant in the workings of political society.

At one level 'active citizenship' is unexceptionable. One can hardly advocate 'bad neighbourliness'. On the other hand, there are problems. Who, for example, sets the agenda of 'socially beneficial' initiatives - voluntary bodies or the state? The very association of voluntary bodies with the state may deprive their members and clients of 'ownership' of those bodies. The vital role of voluntary associations as potential critics of government policy is also blunted if their criticism leads to a withdrawal of state funding, or, even more seriously, of access to the locus of power.

Moreover, imposing citizenship on the school curriculum can be criticised as producing a bland and conformist citizenry, 'voluntarily' doing the government's bidding while being rendered intellectually and emotionally incapable of critical analysis and evaluation of the effects. It is worth noting that all the totalitarian regimes of the twentieth century have been keen to promote such 'voluntary' activity by their citizens.

Finally, one could argue that the government is shifting responsibility for what is properly its own function on to the shoulders of its people. These functions include, for instance, care of the elderly, reduction of street crime and preservation of the environment.

\section{Summary}

Rights in some sense existed in the Middle Ages, although the idea of 'human rights' dates from the eighteenth century. Historically, there has been some debate on what exactly these rights consist of, while conservatives and 
socialists have, from different directions, supported the liberal commitment to universal human rights. By the end of the nineteenth century it was widely agreed that a focus on 'individual' and 'negative rights' was inadequate to meet the social needs of the time. This led to the development of 'group' and 'social' rights, such as those accorded to groups like trade unions and to individuals in the form of welfare benefits. Critics have questioned whether social rights are properly so described; the expression 'aspirations' might be more appropriate. Obligations, or duties, to society and the state have received considerable attention in recent years, partly in an attempt to give them a sound philosophical underpinning and partly to establish what are the limits to the individual's duty to the state. Governments, especially 'New Labour', have been anxious to incorporate the idea of obligations as well as rights into the political consensus. Citizenship has been subject to some reappraisal in recent years. It is a reappraisal that moves away from a purely legal definition to a concept that includes full participation of citizens in the democratic process.

\section{REFERENCES AND FURTHER READING}

1 Edmund Burke, Reflections on the Revolution in France (1790).

2 Archbishop Oscar Romero, quoted in Anthony Jay (ed.), Oxford Dictionary of Political Quotations (Oxford University Press, 1999), p. 308.

Barbalet, J. M. Citizenship (Open University Press, 1988).

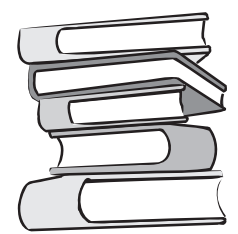

Cranston, M. What are Human Rights? (The Bodley Head, 1973).

Dworkin, R. Taking Rights Seriously (Duckworth, 1979).

Heywood, A. 'Rights, Obligations and Citizenship', ch. 6 in A. Haywood, Political Ideas and Concepts: An Introduction (Macmillan, 1994), pp. 137-65.

Finnis, J. Natural Law and Natural Rights (Clarendon Press, 1980).

Flathman, R. Political Obligation (Atheneum, 1972).

Heater, D. Citizenship: The Civil Ideal in World History, Politics and Education (Longman, 1990).

Meldon, A. (ed.) Human Rights (Wadsworth, 1970).

Pateman, C. The Problem of Political Obligation (Wiley, 1979).

Raphael, D. D. (ed.) Political Theory and the Rights of Man (Macmillan, 1967).

Waldren, J. The Problems of Rights (Oxford University Press, 1984). 


\section{SAMPLE QUESTIONS}

1 Compare and contrast the liberal, socialist and conservative concepts of rights.

2 To what extent is belief in human rights founded on reason?

3 What is the basis of political obligation in a democracy?

4 Is rebellion against the state ever justified?

5 Are there fundamental differences between the democratic and totalitarian concepts of citizenship?

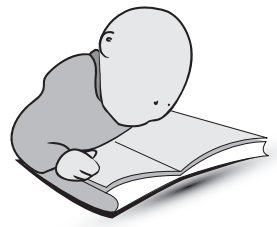

6 'All too often modern concepts of citizenship tend to over-emphasise the rights a citizen has and to ignore the corresponding duties associated with citizenship.' Discuss. 